\title{
Relationship Between Decay Accelerating Factor Deficiency, Diminished Acetylcholinesterase Activity, and Defective Terminal Complement Pathway Restriction in Paroxysmal Nocturnal Hemoglobinuria Erythrocytes
}

\author{
M. E. Medof, A. Gottlieb, T. Kinoshita, S. Hall,“ R. Silber, V. Nussenzweig, and W. F. Rosse* \\ Department of Pathology, New York University Medical Center, New York 10016; and *Department of Medicine, \\ Duke University Medical Center, Durham, North Carolina 27710
}

\begin{abstract}
Paroxysmal nocturnal hemoglobinuria (PNH) erythrocytes exhibit abnormalities in decay accelerating factor (DAF), acetylcholinesterase, and resistance to autologous C5b-9 attack. To investigate the nature of the lesion underlying PNH cells, we examined the relationship of these abnormalities to one another. Analyses of DAF in acetylcholinesterase-negative erythrocytes revealed that these two abnormalities involve functionally independent molecules, coincide precisely in the same cell populations, and are similarly expressed in PNH II and more complement-sensitive PNH III erythrocytes. The DAF and acetylcholinesterase deficiencies contrast with the $\mathrm{C} 3 \mathrm{~b} / \mathrm{C} 4 \mathrm{~b}$ receptor (CR1) deficit, which is less profound and similarly distributed in complement-insensitive cell populations. Hemolytic studies showed that defective resistance to autologous C5b-9 attack is mediated by another mechanism. Whereas reconstitution of PNH II erythrocytes with DAF completely corrected their complement sensitivity, DAF reconstitution of PNH III erythrocytes restored their ability to circumvent $\mathrm{C} 3 \mathrm{~b}$ uptake but had no effect on their heightened susceptibility to reactive lysis. Assays of complementinsensitive (PNH I) erythrocytes surviving after reactive lysis disclosed partial DAF and acetylcholinesterase deficits. These findings indicate that the PNH lesion involves multiple membrane components and that PNH I erythrocytes are also abnormal.
\end{abstract}

\section{Introduction}

Paroxysmal nocturnal hemoglobinuria (PNH) ${ }^{1}$ is an acquired disorder in which variable proportions of blood elements sensitive to the lytic action of autologous complement appear in the circulation (reviewed in reference 1). It is thought that the

This work was presented in part at the XIth International Complement Workshop, Key Biscayne, FL, November 1985.

Dr. Medof's current address is Department of Pathology, Case Western Reserve University, Cleveland, OH 44106.

Received for publication 11 September 1986 and in revised form 26 December 1986.

1. Abbreviations used in this paper: $\mathrm{AChE}$, acetylcholinesterase; $\mathrm{C}$-EDTA, C3-9 reagent; $C L S$, complement lysis sensitivity; $C R 1, C 3 b / C 4 b$ receptor, DAF, decay accelerating factor, $E^{\text {hu }}$, human erythrocyte; $E^{\text {hu }} A, E^{\text {hu }} A C 1$, $E^{\text {hu }} \mathrm{ACl}$, and $\mathrm{E}^{\text {hu }} \mathrm{ACl} 1423$, complement intermediates bearing respective components; FACS, fluorescence-activated cell sorter, NP40, NonidetP40 detergent; PNH, paroxysmal nocturnal hemoglobinuria.

J. Clin. Invest.

(c) The American Society for Clinical Investigation, Inc.

0021-9738/87/07/0165/10 $\$ 2.00$

Volume 80, July $1987,165-174$ aberrant circulating cells originate from the clonal proliferation of bone marrow progenitors altered by somatic mutation. Considerable experimental data have shown that their complement sensitivity is due to intrinsic defects in their cell membranes. Two groups of investigators found that they are deficient (2-4) in a complement regulatory protein termed decay accelerating factor (DAF) (5-11), establishing a molecular basis for their abnormal interaction with the complement system.

Recently, it was observed that purified DAF could be incorporated into cell membranes in vitro (8) and that, once cellassociated, the exogenous DAF could move freely in the plane of the membrane and exert its activity. It was shown from studies exploiting this phenomenon that in situ DAF could prevent the assembly of $\mathrm{C} 3$ and $\mathrm{C} 5$ convertases of both complement pathways on cell surfaces and thereby could protect cells from complement attack. To examine the role of DAF deficiency in the lytic abnormalities of PNH cells, DAF was restored to affected PNH erythrocytes $\left(E^{\text {hu }}\right)(12)$. Reconstitution of the DAF-deficient PNH $E^{\text {hu }}$ with DAF corrected their excessive C3b uptake. The DAF reconstitution, however, had only a partial effect on acid lysis susceptibility of the affected cells. Although physiologic DAF levels were not achieved in these studies, this finding raised the possibility that other membrane defects that could preclude complete correction of the lytic sensitivity by DAF might exist in the PNH cells.

Several alterations have been reported in the membranes of PNH E ${ }^{\text {hu }}$ (1). Affected cells not only take up excessive amounts of $\mathrm{C} 3 \mathrm{~b}$, but they are characteristically deficient in membrane acetylcholinesterase (AChE). Additionally, whereas PNH II E ${ }^{\text {hu }}$, found in some patients, are three- to fivefold more sensitive to complement than normal $E^{\text {hu }}$, PNH III $E^{\text {hu }}$, present in the majority of patients, are 15- to 25-fold more sensitive. The PNH III $\mathrm{E}^{\text {hu }}$ are markedly more susceptible than normal $\mathrm{E}^{\text {hu }}$ to bystander lysis by fluid-phase terminal pathway complexes (e.g., C5b-9). There is experimental evidence suggesting that the vulnerability of PNH III $\mathrm{E}^{\text {hu }}$ to this passive lysis may be due to a defect in the capacity of the affected cells to restrict insertion and/or polymerization of autologous C9 (13-17) as well as to a defect in their ability to circumvent uptake of C3b.

Whether DAF and AChE deficiencies overlap in affected PNH E $E^{\text {hu }}$ and are separate abnormalities and whether either is involved in the heightened sensitivity of PNH III cells to bystander lysis are not known. The present study was undertaken to investigate the relationship of these three abnormalities in affected PNH E ${ }^{\text {hu }}$.

\section{Methods}

Buffers, reagents, and labeling. Isotonic veronal contained $2.5 \mathrm{mM}$ barbital, pH 7.4, $73 \mathrm{mM} \mathrm{NaCl}, 2.5 \%$ dextrose, $0.15 \mathrm{mM} \mathrm{CaCl}_{2}, 0.5 \mathrm{mM}$ $\mathrm{MgCl}_{2}$, and $0.1 \%$ gelatin. Isoionic veronal contained $146 \mathrm{mM} \mathrm{NaCl}$ in 
place of $73 \mathrm{mM} \mathrm{NaCl}$ and $2.5 \%$ dextrose. Metal-chelating veronal was prepared as isoionic veronal but contained $10 \mathrm{mM}$ EDTA in place of metals. Phosphate-buffered saline (PBS) contained $10 \mathrm{mM}$ sodium phos-

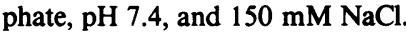

Nonidet-P40 detergent (NP40) was purchased from Particle Data, Inc. (Elmhurst, IL), phenylmethylsulfonyl fluoride and Clostridium neuraminidase (type VI) from Sigma Chemical Corp. (St. Louis, MO), and the synthetic elastase inhibitor, Suc-(OMe)-Ala-Ala-Pro-Val-MCA, from Peninsula Laboratories Inc. (Belmont, CA).

Proteins and $\mathrm{E}^{\text {hu }}$ were labeled by Iodogen (Pierce Chemical Co., Rockford, IL) according to the manufacturer's instructions. In the case of the cells, $0.5 \mathrm{mCi}^{125} \mathrm{I}$ per $10^{9} \mathrm{E}^{\mathrm{hu}}$ was used, and the procedure described in reference 18 followed.

Purified proteins and antibodies. C2 (19), C4 (20), C3 (20), C5 (20), C6-9 (21), guinea pig C1 (22), and guinea pig and human C3-9 (CEDTA) (22) were prepared as described. Cobra venom factor was purified by the method in reference 23 .

DAF was isolated from butanol extracts of pooled $E^{\text {hu }}$ stroma as described $(8,9)$. The purified product had characteristic mobility on sodium dodecyl sulfate-polyacrylamide gel electrophoresis (SDS-PAGE) gels (see inset of Fig. 1, reference 8); it was devoid of glycophorin as assessed by Western blotting using antiglycophorin antibodies, and by SDS-PAGE and radioautography after radiolabeling. For some experiments, DAF was concentrated and the NP40 concentration reduced to $0.0006 \%$ by affinity chromatography employing Sepharose coupled to (IA10) monoclonal anti-DAF antibodies. The anti-DAF conjugate was cross-linked with glutaraldehyde, and the column eluted with $0.05 \mathrm{M}$ diethylamine, 0.025 M Tris, 0.020 M EDTA, 0.0006\% NP40, pH 11.5 buffer. Human $\mathrm{C} 3 \mathrm{~b} / \mathrm{C} 4 \mathrm{~b}$ receptor (CR1) was purified from $1 \%$ NP40 extracts of pooled $E^{\text {hu }}$ stroma by chromatography on Biorex 70 (24) followed by affinity chromatography on Sepharose coupled to (44D) monoclonal anti-CR1 antibody (25). The isolation was performed as described for DAF except that bound CR1 was eluted from the antiCR1 conjugate with $3.0 \mathrm{M} \mathrm{KSCN}$.

Rabbit IgM hemolysin was a gift of Dr. Eric Brown (Washington University, St. Louis, MO). Rabbit anti-glycophorin antibodies were prepared as described in reference 8; monoclonal antibodies to glycophorin A were raised from a hybridoma donated by Dr. Margaret Nichols

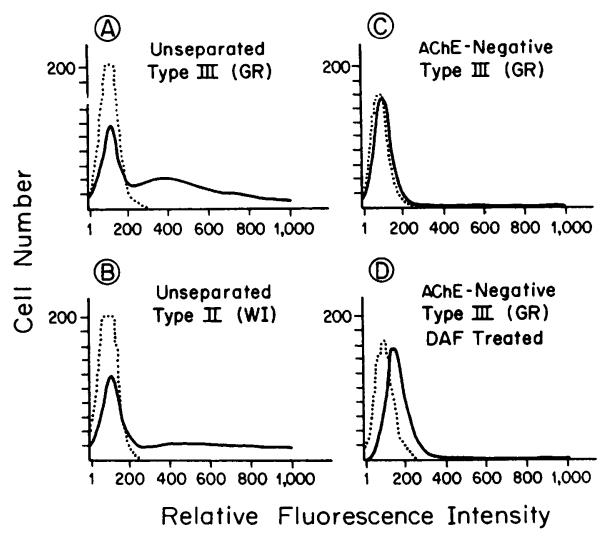

Figure 1. FACS analyses of DAF in unseparated and purified AChEnegative PNH $E^{\text {hu }}$ before and after reconstitution of the cells with exogenous DAF. The untreated or DAF-treated $\mathrm{E}^{\text {hu }}$ were stained with a mixture of three monoclonal anti-DAF antibodies followed by fluorescein isothiocyanate-labeled goat $\mathrm{F}\left(\mathrm{ab}^{\prime}\right)_{2}$ anti-mouse Ig. Dashed lines show the background fluorescence of control cells stained with three nonrelevant antimalaria monoclonal antibodies in place of the anti-DAF monoclonals. $(A)$ Unseparated $\mathrm{E}^{\text {hu }}$ from patient W.I. with PNH II E $E^{\text {hu }} ;(B)$ unseparated $E^{\text {hu }}$ from patient G.R. with PNH III $E^{\text {hu, }}$ $\left(C\right.$ and $D$ ) purified AChE-negative $\mathrm{E}^{\text {hu }}$ from patient G.R. before and after DAF treatment.
(New York Blood Center). Serum containing anti-I cold agglutinin was obtained from patient J.S. with chronic cold agglutinin disease (26).

Rabbit anti-DAF antibodies were prepared as in reference 8 . They were monospecific as assessed by immunoblotting with crude extracts of $\mathrm{E}^{\text {hu }}$ stroma. Rabbit anti-( $\mathrm{E}^{\text {hu }}$-associated)-AChE antibodies were a gift of Dr. Lucio Luzzatto (University of Naples, Naples, Italy). Mouse monoclonal anti-DAF antibodies (IA10, IIH6, and VIIIA7) were obtained as described in reference 9. Hybridomas (AE1 and AE2) producing monoclonal anti-( $\left.E^{\text {hu }}\right)-A C h E$ antibodies (27) were obtained from the American Tissue Type Collection (Rockville, MD). Monoclonal antiCR1 antibodies (44D, 57F, 31D, and 57H) (24) and control anti-malaria antibodies (3D11, 2G3, 6G2, and 2A10) of appropriate subtypes were prepared as described (28). Anti-DAF, -CR1, and -malaria monoclonals were purified by $\left(\mathrm{NH}_{4}\right)_{2} \mathrm{SO}_{4}$ precipitation and DEAE-Sephacel chromatography. Anti-AChE monoclonals were used as ascites fluids.

Fluorescein-isothiocyanate-conjugated goat $F\left(a b^{\prime}\right)_{2}$ anti-mouse Ig and rabbit anti-mouse Ig were from Cappel Laboratories (Cochranville, PA), protein-A agarose suspension from Zymed Labs Inc. (San Francisco, CA), and protein-A Sepharose CL-4B from Pharmacia, Inc. (Piscataway, $\mathrm{NJ}$ ).

Measurements of DAF and CR1 levels. Levels of DAF and CR1 in $E^{\text {hu }}$ were quantitated by two-site radioimmunometric assays employing the respective monoclonal antibodies as described in references 9 and 25. $\mathrm{E}^{\text {hu }}$ samples were lysed with $1 \% \mathrm{NP40}$ (at $5 \times 10^{9} / \mathrm{ml}$ in the case of DAF and $2 \times 10^{10} / \mathrm{ml}$ in the case of CR1), diluted 10-fold (in PBS containing $1 \mathrm{mM}$ phenylmethylsulfonyl fluoride and $50 \mu \mathrm{g} / \mathrm{ml}$ synthetic elastase inhibitor), and clarified by centrifugation. The amounts of DAF or $\mathrm{CR} 1$ in the $\mathrm{E}^{\text {hu }}$ samples were determined by reference to standard curves generated using increasing amounts of the respective purified membrane proteins.

Surface expression of DAF on $E^{\text {hu }}$ was assessed by flow cytometry using a fluorescence-activated cell sorter (FACS) (Ortho Diagnostics, Westwood, MA) as described in reference 9. The $\mathrm{E}^{\text {hu }}\left(10^{6}\right.$ cells in $25 \mu \mathrm{l}$ of PBS containing $1 \%$ bovine serum albumin [BSA]) were incubated on ice for $30 \mathrm{~min}$ with pooled monoclonal anti-DAF antibodies $(5 \mu \mathrm{g} / \mathrm{ml}$ each in $25 \mu \mathrm{l}$ of the same buffer) or, as a control, with a mixture of nonrelevant (antimalaria) monoclonal antibodies at the same concentrations. After washing, the $\mathrm{E}^{\text {hu }}$ were resuspended to $25 \mu \mathrm{l}$ in PBS containing $1 \% \mathrm{BSA}$, and incubated on ice for $30 \mathrm{~min}$ with an equal volume of a 1:50 dilution of fluorescein-isothiocyanate-goat $\mathrm{F}\left(\mathrm{ab}^{\prime}\right)_{2}$ anti-mouse Ig. The treated cells were washed again and resuspended to $1 \mathrm{ml}$ in the same buffer.

Hemolytic assays. Efficiency of classical C3 convertase, C4b2a, assembly on $E^{\text {hu }}$ was assessed as described in reference 12 . $E^{\text {hu }}$ were sensitized with rabbit IgM hemolysin to provide $50 \mathrm{C} 1$ fixing sites per cell (29). After washing, the $\mathrm{E}^{\text {hu }} \mathrm{A}\left(1 \times 10^{8} / \mathrm{ml}\right.$ in isotonic veronal buffer $)$ were incubated at $30^{\circ} \mathrm{C}$ for $15 \mathrm{~min}$ with $\mathrm{Cl}$ at a concentration 10 -fold higher than that required for maximum uptake of $\mathrm{C} 4$. Washed $\mathrm{E}^{\text {hu }} \mathrm{ACl}\left(1 \times 10^{8}\right)$ $\mathrm{ml}$ in isotonic veronal) were incubated for $15 \mathrm{~min}$ at $30^{\circ} \mathrm{C}$ with increasing concentrations of $\mathrm{C} 4$. The number of $\mathrm{C} 4 \mathrm{~b}$ molecules deposited at each $\mathrm{C} 4$ input was determined by employing ${ }^{125}$ I-labeled $\mathrm{C} 4$ in parallel studies. The $\mathrm{E}^{\mathrm{hu}} \mathrm{AC} 14\left(1 \times 10^{8} / \mathrm{ml}\right.$ in isotonic veronal $)$ bearing increasing numbers of $\mathrm{C} 4 \mathrm{~b}$ per cell were mixed with $\mathrm{C} 2$ adjusted to a concentration 10 -fold higher than that giving maximum lysis of $\mathrm{E}^{\mathrm{hu}} \mathrm{ACl} 4$ prepared with limited $\mathrm{C} 4$ and treated with anti-DAF antibodies. After incubation at $30^{\circ} \mathrm{C}$ for $5 \mathrm{~min}$, hemolytic activity was developed by addition of $1.8 \mathrm{ml}$ of C3-9 reagent (C-EDTA 1:20 in metal-chelating veronal buffer) and further incubation at $37^{\circ} \mathrm{C}$ for $60 \mathrm{~min}$.

Complement lysis sensitivity (CLS) of $\mathrm{E}^{\text {hu }}$ was assessed as described by Rosse and Dacie $(26,30)$. $\mathrm{E}^{\text {hu }}\left(2 \times 10^{8} / \mathrm{ml}\right.$ in isoionic veronal buffer) were mixed at $37^{\circ} \mathrm{C}$ with an equal volume of anti-I serum (1:50 in 0.15 $\mathrm{M} \mathrm{NaCl}) .50-\mu \mathrm{l}$ aliquots of the $\mathrm{E}^{\mathrm{hu}}$ anti-I mixtures were added to increasing volumes of $1: 270,1: 90,1: 30$, or 1:10 normal human serum. The resulting mixtures were preincubated at $0^{\circ} \mathrm{C}$ for $30 \mathrm{~min}$, placed at $37^{\circ} \mathrm{C}$, and after $1 \mathrm{~h}$ isoionic veronal buffer was added, the tubes centrifuged, and lysis read. The relative sensitivity of the cells was expressed in CLS H50 units (26). 
Susceptibility of the $E^{\text {hu }}$ to reactive lysis was assessed using cobra venom factor as described in reference 23 . Portions $(100 \mu \mathrm{l})$ of $\mathrm{E}^{\text {hu }}(1$ $\times 10^{8} / \mathrm{ml}$ in metal-chelating veronal buffer) were mixed with equal volumes of fresh human serum diluted 1:4 to 1:64 in the same buffer. Cobra venom factor: $\mathrm{Bb}$ complexes, prepared by incubation of cobra venom factor $(1 \mathrm{mg} / \mathrm{ml}$ in isoionic veronal buffer $)$ at $37^{\circ} \mathrm{C}$ for $2 \mathrm{~h}$ with an equal volume of (neat) serum, were diluted 1:32 in metal-chelating veronal buffer, and 50- $\mu$ l aliquots of the diluted complexes were added to the various $\mathrm{E}^{\text {hu }}$ serum mixtures. The reaction tubes were placed at $37^{\circ} \mathrm{C}$, and after $1 \mathrm{hr}, 4 \mathrm{ml}$ of metal-chelating veronal buffer was added, the tubes centrifuged, and lysis read.

Immunoprecipitation, SDS-PAGE, and autoradiography. The NP40 extract of $10^{9}{ }^{125} \mathrm{I}$-surface-labeled $\mathrm{E}^{\text {hu }}$ was diluted to $1 \mathrm{ml}$ with PBS and cleared by rotation at $0^{\circ} \mathrm{C}$ for $30 \mathrm{~min}$ with $10 \% \mathrm{vol} / \mathrm{vol}$ protein A-agarose suspension in $15 \mathrm{mM} \mathrm{NaCl}, 9 \mathrm{mM}$ EDTA, $50 \mathrm{mM}$ Tris, pH 7.4, containing $0.05 \%$ NP40 and $1 \mathrm{mg} / \mathrm{ml}$ ovalbumin. After centrifugation, 250 $\mu \mathrm{l}$ aliquots of the supernatant were rotated at $0^{\circ} \mathrm{C}$ for $30 \mathrm{~min}$ with pooled monoclonal anti-DAF antibodies (IA10, IIH6, and VIIIA7), $5 \mu \mathrm{g} / \mathrm{ml}$ each, individual anti-AChE antibodies (AE1 or AE2), $5 \mu \mathrm{g} / \mathrm{ml} \mathrm{each,}$ or with pooled antimalaria monoclonals (3D11, 2G3, 2A10), $5 \mu \mathrm{g} / \mathrm{ml}$ each. After rotation at $0^{\circ} \mathrm{C}$ for $30 \mathrm{~min}$, immune complexes were precipitated by addition of $100 \mu \mathrm{l}$ of protein A-agarose suspension and centrifugation. After washing twice in $15 \mathrm{mM} \mathrm{NaCl}, 9 \mathrm{mM}$ EDTA, $50 \mathrm{mM}$ Tris, pH 7.4, containing $0.05 \%$ NP40, transfer to new tubes, and washing again in the same buffer, precipitated proteins were eluted by resuspending the agarose beads in $\mathbf{5 0 \mu}$ l of SDS-PAGE loading buffer containing $20 \%$ 2-mercaptoethanol, boiling for $3 \mathrm{~min}$, and collection of the supernatants.

SDS-PAGE analysis of eluted proteins was carried out on $7.5 \%$ slab gels according to the method of Laemmli (31). After fixation and drying, autoradiographs of the gels were obtained at $-70^{\circ} \mathrm{C}$ with X-Omat XAR5 film (Eastman Kodak Co., Rochester, NY).

Purification of $A C h E$-negative $E^{\text {hu }}$. AChE-negative $\mathrm{E}^{\text {hu }}$ from PNH patients were separated as described in reference $32.25 \mu \mathrm{l}$ of AE1 monoclonal anti-AChE ascites fluid was added to $2 \mathrm{ml}$ of $\mathrm{E}^{\text {hu }}$ from the patients $\left(1 \times 10^{9} \mathrm{E}^{\mathrm{hu}} / \mathrm{ml}\right.$ in PBS$)$ and the mixtures rocked at $20^{\circ} \mathrm{C}$ for $30 \mathrm{~min}$. The cells were pelleted, washed twice in PBS containing $1 \%$ BSA, and mixed with $1 \mathrm{ml}$ of rabbit anti-mouse IgG. After another incubation at $20^{\circ} \mathrm{C}$ for $30 \mathrm{~min}$ and thorough washing in the same buffer, the cells were loaded onto protein A Sepharose CL-4B $\left(2 \times 10^{8} \mathrm{E}^{\text {hu }} / \mathrm{ml}\right.$ packed gel $)$ equilibrated at $20^{\circ} \mathrm{C}$ in PBS. The column was opened and unbound cells collected by washing with $1 \mathrm{ml}$ of PBS followed by PBS containing $1 \%$ BSA.

Patients. PNH patients were followed at Duke University Medical Center. All had consistent clinical presentations and characteristic abnormalities of their $\mathrm{E}^{\text {hu }}$ in the Ham and/or CLS assays.

\section{Results}

Relationship between deficiencies of DAF and of AChE in PNH $E^{\text {hu }}$. Recent analyses of PNH $E^{\text {hu }}$ with monoclonal anti-AChE antibodies (32) have shown that diminished membrane AChE enzyme activity (33) is due to deficiency in affected cells of the membrane AChE enzyme molecule. Initial studies were performed to establish whether the AChE deficiency coincides in the same cells as DAF deficiency, whether expression of the two defects differs in PNH II and PNH III E ${ }^{\text {hu }}$, and whether the two defects are separate abnormalities.

In the first series of experiments, the distributions of the two defects in PNH II and PNH III $\mathrm{E}^{\text {hu }}$ were examined by purifying AChE-negative $E^{\text {hu }}$ from patients by cell-affinity chromatography (see Methods) and assaying them for DAF content by two-site radioimmunometric assay employing anti-DAF monoclonals. Table I shows the results in relation to DAF levels measured in unseparated $E^{\text {hu }}$ from the same patients. In all eight patients studied, DAF levels in the purified AChE-negative cell populations were zero, indicating that the DAF and $\mathrm{AChE}$ deficits in PNH coincide in the same cells. PNH II and PNH III AChEnegative $E^{\text {hu }}$ were both totally DAF-deficient, indicating that the differences in complement sensitivity between these two classes of PNH $E^{\text {hu }}$ do not reflect differences in DAF contents. DAF levels in the AChE-positive (adherent) $E^{\text {hu }}$ subpopulation from each of the patients were calculated by dividing the total DAF

Table I. DAF and CRI Levels in PNH Erythrocytes

\begin{tabular}{|c|c|c|c|c|c|c|}
\hline \multirow[b]{2}{*}{ Patient ID } & \multirow{2}{*}{$\begin{array}{l}\text { \% Affected } \\
\text { cells }\end{array}$} & \multicolumn{2}{|c|}{ Unfractionated erythrocytes } & \multicolumn{2}{|c|}{$\begin{array}{l}\text { Purified AChE-negative } \\
\text { erythrocytes }\end{array}$} & \multirow{2}{*}{$\begin{array}{l}\text { AChE-positive } \\
\text { erythrocytes }\end{array}$} \\
\hline & & DAF & CR1 & DAF & CRI & \\
\hline & & molecules/cell & $n g / 10^{9}$ & molecules/cell & $n g / 10^{9}$ & molecules/cell \\
\hline \multicolumn{7}{|l|}{ PNH III } \\
\hline M.A. & 50 & 482 & 162 & 0 & 121 & 964 \\
\hline D.I. & 58 & 361 & 231 & $<10$ & 205 & 859 \\
\hline P.H. & 34 & 963 & 158 & $<10$ & 185 & 1459 \\
\hline J.F. & 60 & 740 & 165 & 0 & 198 & 1850 \\
\hline F.R. & 35 & 568 & 162 & 0 & 206 & 873 \\
\hline \multicolumn{7}{|l|}{ PNH IIIb } \\
\hline G.R. & 52 & 1471 & 244 & 0 & 253 & 3065 \\
\hline \multicolumn{7}{|l|}{ PNH II } \\
\hline W.I. & 42 & 1066 & 99 & $<10$ & - & 1837 \\
\hline B.A. & 90 & 172 & 180 & 0 & 130 & 1710 \\
\hline \multicolumn{7}{|l|}{ Normals } \\
\hline$\overline{\mathbf{x}}$ & & $2600^{8}$ & $376^{\prime \prime}$ & & & \\
\hline SD & & 320 & 144 & & & \\
\hline
\end{tabular}

* By calculation. ${ }^{\ddagger}$ Comparable sensitivity to PNH III in reactive lysis but sensitivity to classical pathway lysis intermediate between PNH II and III. $n=35$ (reference 9). " $n=10$. 
present in the unfractionated $\mathrm{E}^{\text {hu }}$ by the proportion of DAFcontaining cells in the sample and are shown for comparison in the last column of the table. In all but one case, these levels were also reduced and, in three cases, were $<50 \%$ of normal indicating that a less pronounced DAF defect was present in the AChEpositive cells of most patients. CR1 contents of the unfractionated and the purified AChE-negative cells of the patients, as determined by a parallel two-site radioimmunometric assay employing anti-CR1 monoclonals, are additionally shown. Although $\mathrm{CR} 1$ levels in the unfractionated $\mathrm{E}^{\text {hu }}$ of all cases were diminished, the extent of CR1 reduction in the AChE-negative and -positive $E^{\text {hu }}$ populations of each patient were comparable. The $C R 1 \mathrm{ab}-$ normality thus constitutes a less severe deficiency that does not segregate with AChE or DAF deficiency.

In the next series of experiments, the overlap of DAF deficiency in the AChE-negative $\mathrm{E}^{\text {hu }}$ population of each patient was verified in FACS analyses. The results of a representative study are shown in Fig. 1. The distributions of DAF in unfractionated $E^{\text {hu }}$ from two of the patients and in AChE-negative cells from one of them are shown. Consistent with the previous findings, DAF-deficient PNH II E ${ }^{\text {hu }}$ (Fig. $1 A$ ) appeared identical to DAFdeficient PNH III $E^{\text {hu }}$ (Fig. $1 B$ ) with respect to extent of DAF deficiency, both coinciding with the negative controls. Purified AChE-negative cells from the latter patient (Fig. $1 C$ ) comprised a single population containing no DAF-bearing cells. Control studies with anti-AChE monoclonals revealed no AChE-positive $\mathrm{E}^{\text {hu }}$. Identical results were obtained in FACS analyses of AChEnegative $\mathrm{E}^{\text {hu }}$ from all other patients studied.

The relationship between the proteins responsible for $\mathrm{AChE}$ and DAF activities was next examined in studies employing anti-DAF and anti-AChE monoclonals. First, structural studies were performed. Normal $E^{\text {hu }}$ were surface-labeled with ${ }^{125} \mathrm{I}$, and the washed stroma extracted with $1 \%$ NP40. Aliquots of the extract were immunoprecipitated with pooled monoclonal antiAChE, anti-DAF, or nonrelevant (antimalaria) antibodies, and immunoprecipitated proteins were analyzed by SDS-PAGE followed by radioautography. As shown in Fig. 2, the anti-AChE and anti-DAF monoclonals precipitated distinct proteins that differed slightly in apparent $M_{\mathrm{r}}$. Parallel studies with neuraminidase-pretreated $\mathrm{E}^{\text {hu }}$ revealed a decrease in the apparent $M_{\mathrm{r}}$ of DAF but not of AChE. In a second set of experiments functional analyses were carried out. Preincubation of the normal $\mathrm{E}^{\text {hu }} \mathrm{AC} 14$ with polyclonal $(100 \mu \mathrm{g} / \mathrm{ml}$ IgG) or pooled monoclonal $(100 \mu \mathrm{g} /$ $\mathrm{ml}$ each) anti-AChE antibodies had no effect on the ability of the cells to restrict $\mathrm{C} 4 \mathrm{~b} 2 \mathrm{a}$ assembly and subsequent lysis upon addition of human $\mathrm{C} 2$ and heterologous guinea pig C3-9 (a source of terminal pathway components not inhibited by human cell factors which can be used to assay uptake of autologous C3b $[13,14])$. In contrast, under the same conditions, $<5 \mu \mathrm{g} / \mathrm{ml}$ each of pooled monoclonal anti-DAF antibodies completely overcame membrane DAF activity and rendered the cells susceptible to lysis (not shown). Alternatively, pretreatment of normal $E^{\text {hu }}$ with $50 \mu \mathrm{g} / \mathrm{ml}$ polyclonal anti-DAF antibodies rendered them PNH-like in acid lysis (12) but had no effect on membrane AChE enzyme activity, whereas treatment with $5 \mu \mathrm{g} / \mathrm{ml}$ of antiAChE antibodies completely abrogated enzyme function (32). Conversely, reconstitution of AChE-deficient PNH $\mathrm{E}^{\text {hu }}$ with DAF did not restore AChE enzyme activity to the cells. The deficiencies of DAF and of AChE in affected PNH $E^{\text {hu }}$ thus constitute defects in two separate entities with independently mediated activities.

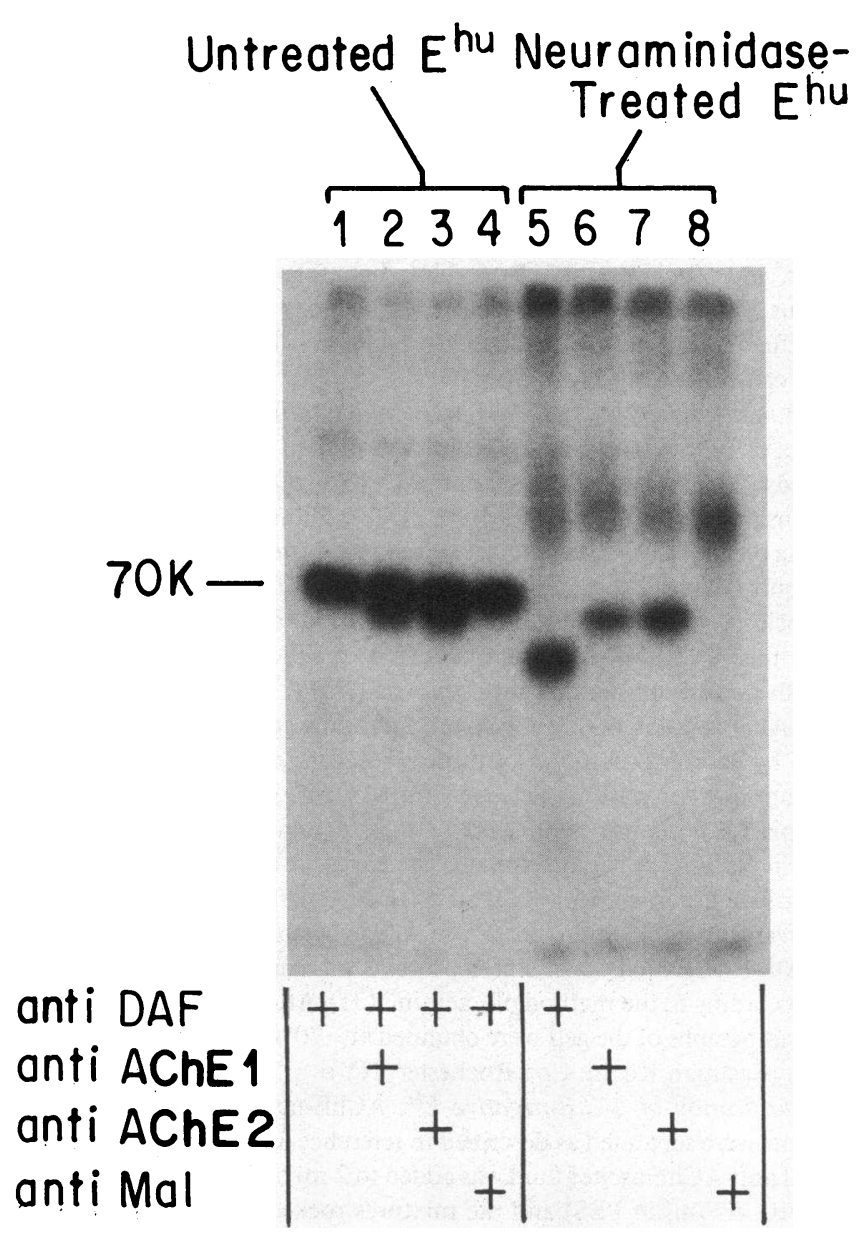

Figure 2. Differential immunoprecipitation of membrane DAF and AChE. $E^{\text {hu }}$ were incubated at $37^{\circ} \mathrm{C}$ for $2 \mathrm{~h}$ with $3 \mathrm{U}$ of type VI neuraminidase. $E^{\text {hu }}$ untreated or pretreated with neuraminidase were surface labeled with ${ }^{125} \mathrm{I}$, and after hypotonic lysis the membranes were extracted with $1 \%$ NP40. Extracts of untreated $E^{\text {hu }}$ were incubated with either pooled monoclonal anti-DAF antibodies (lane 1), antiDAF and anti-AChE monoclonal AE1 together (lane 2), anti-DAF and anti-AChE monoclonal AE2 together (lane 3), or pooled antiDAF and antimalaria monoclonals (lane 4). Extracts of neuraminidase-treated cells were incubated with either pooled anti-DAF monoclonals (lane 5), anti-AChE AE1 alone (lane 6), anti-AChE AE2 alone (lane 7), or pooled antimalaria monoclonals (6G2, 2A10) (lane 8). After addition of protein A-agarose, the immunoprecipitated proteins were extracted with SDS, subjected to SDS-PAGE on $7.5 \%$ gels, and radioautographs prepared. The anti-DAF and anti-AChE monoclonals precipitated different proteins and, unlike DAF, membrane AChE did not decrease in size following pretreatment of the cells with neuraminidase.

Relationship between DAF and AChE deficiencies and defective terminal pathway restriction in $P N H E^{\text {hu }}$. Increased sensitivity to lytic terminal pathway complexes (e.g., C5b-9) distinguishes PNH III from PNH II $E^{\text {hu }}(1,15,16)$ and is thought to play a role in the greater susceptibility of the PNH III cells to lysis in vivo. This sensitivity is demonstrable in vitro by markedly greater sensitivity of PNH III than of PNH II $E^{\text {hu }}$ in the CLS assay $(15,16,25)$ and by susceptibility of PNH III but not PNH II $E^{\text {hu }}$ (or normal $E^{\text {hu }}$ ) to lysis in zymosan- (15) or cobra venom factor-treated (21) serum (a source of C5b-9). The intrinsic 
membrane defect of PNH III E ${ }^{\text {hu }}$ responsible for this abnormality is not known. Studies were next conducted to investigate the relationship between this functional defect and the DAF and AChE deficiencies of the cells.

The effects of anti-DAF and anti-AChE antibodies on the capacity of normal cells to restrict membrane damage by autologous $\mathrm{C} 5-9$ were first investigated. Normal $\mathrm{E}^{\text {hu }} \mathrm{AC} 1423$ bearing $\sim 10,000 \mathrm{C} 3 \mathrm{~b}$ per cell were prepared by incubating $\mathrm{E}^{\mathrm{hu}} \mathrm{AC} 14$ with pooled anti-DAF monoclonals, excess human $\mathrm{C} 2$, and human $\mathrm{C} 3(50 \mu \mathrm{g} / \mathrm{ml})$. Upon incubation of the intermediates with guinea pig C5-9 which develops autologous $\mathrm{C} 3 \mathrm{~b}$ sites, immediate lysis was observed. In contrast (despite reincubation with $>1,000$ SFU of C2 or oxidized C2), when the intermediates were incubated with autologous human C5-9 (in place of heterologous guinea pig (3-9) no lysis occurred demonstrating the capacity of normal $E^{\text {hu }}$ to restrict lysis by autologous (as opposed to heterologous) terminal pathway components. Retreatment of the $\mathrm{E}^{\text {hu }} \mathrm{AC} 1423$ with pooled anti-DAF monoclonals $(10-100 \mu \mathrm{g} / \mathrm{ml}$ each), anti-AChE monoclonals (10-100 $\mu \mathrm{g} / \mathrm{ml}$ each), or anti$\mathrm{DAF}$ and anti-AChE monoclonals together, or with polyclonal anti-DAF or anti-AChE antibodies (10-100 $\mu \mathrm{g} / \mathrm{ml} \mathrm{IgG),} \mathrm{sepa-}$ rately or in combination, followed by addition of human C5-9 did not induce lysis, indicating that the resistance of the $\mathrm{C} 3 \mathrm{~b}$ bearing normal $\mathrm{E}^{\text {hu }}$ in human $\mathrm{C} 5-9(13,14)$ is mediated by another entity. In accordance with previous findings $(15,16)$ that PNH E ${ }^{\text {hu }}$ lack this terminal pathway resistance, $E^{\text {hu }} A C 1423$ prepared with PNH III $E^{\text {hu }}$ and bearing $<2,000$ autologous C3b per cell rapidly lysed upon exposure to the human C5-9 (not shown).

The effects of DAF reconstitution on the relative sensitivities of PNH II and III cells in the CLS assay and on the susceptibility of PNH III cells to passive lysis in the presence of cobra venom factor-treated serum were next examined. Unfractionated or affinity-purified AChE-negative PNH $\mathrm{E}^{\text {hu }}$ were reconstituted with DAF or incubated with NP40 detergent as control. Fig. 1, $C$ and $D$ show FACS profiles of AChE-negative cells from one of the patients (G.R.), before and after the DAF reconstitution. In this case employing purified AChE-negative cells, an increase in antiDAF fluorescence of the entire DAF-negative cell population occurred. With unfractionated $\mathrm{E}^{\text {hu }}$, the uptakes of DAF into DAF-deficient and into DAF-containing cell populations were comparable (not shown) suggesting that affected PNH $E^{\text {hu }}$ are not abnormal with respect to their ability to accept DAF.

To establish that DAF molecules incorporated after DAF reconstitution of the PNH cells were functional, the DAF-treated PNH $E^{\text {hu }}$ were tested for their ability to restrict assembly of autologous C4b2a (12). The results of two representative experiments are shown in Fig. 3. In studies with normal $E^{\text {hu }}$ (Fig. 3 $A$ ), despite $>14,000 \mathrm{C} 4 \mathrm{~b}$ per cell, no lysis occurred upon incubation of the cells with $C 2$ followed by guinea pig C3-9 (the developing reagent used to assay $\mathrm{C} 4 \mathrm{~b} 2 \mathrm{a}$ assembly and function). In contrast, significant lysis of the control PNH cells was observed with $<1,000 \mathrm{C} 4 \mathrm{~b}$ per cell, whether AChE-negative (Fig. 3, A and $B$ ) or unfractionated $E^{\text {hu }}$ (Fig. $3 B$ ) were used. After treatment with DAF, the capacity of the PNH cells to circumvent C4b2a assembly was almost completely restored. Measurements with the two-site immunoradiometric assay showed that 344 DAF (Fig. $3 \mathrm{~A}$ ) and 600 DAF (Fig. $3 \mathrm{~B}$ ) molecules per cell had incorporated, respectively. The efficiency of the incorporated DAF in inhibiting $\mathrm{C} 4 \mathrm{~b} 2 \mathrm{a}$ assembly was comparable to that observed
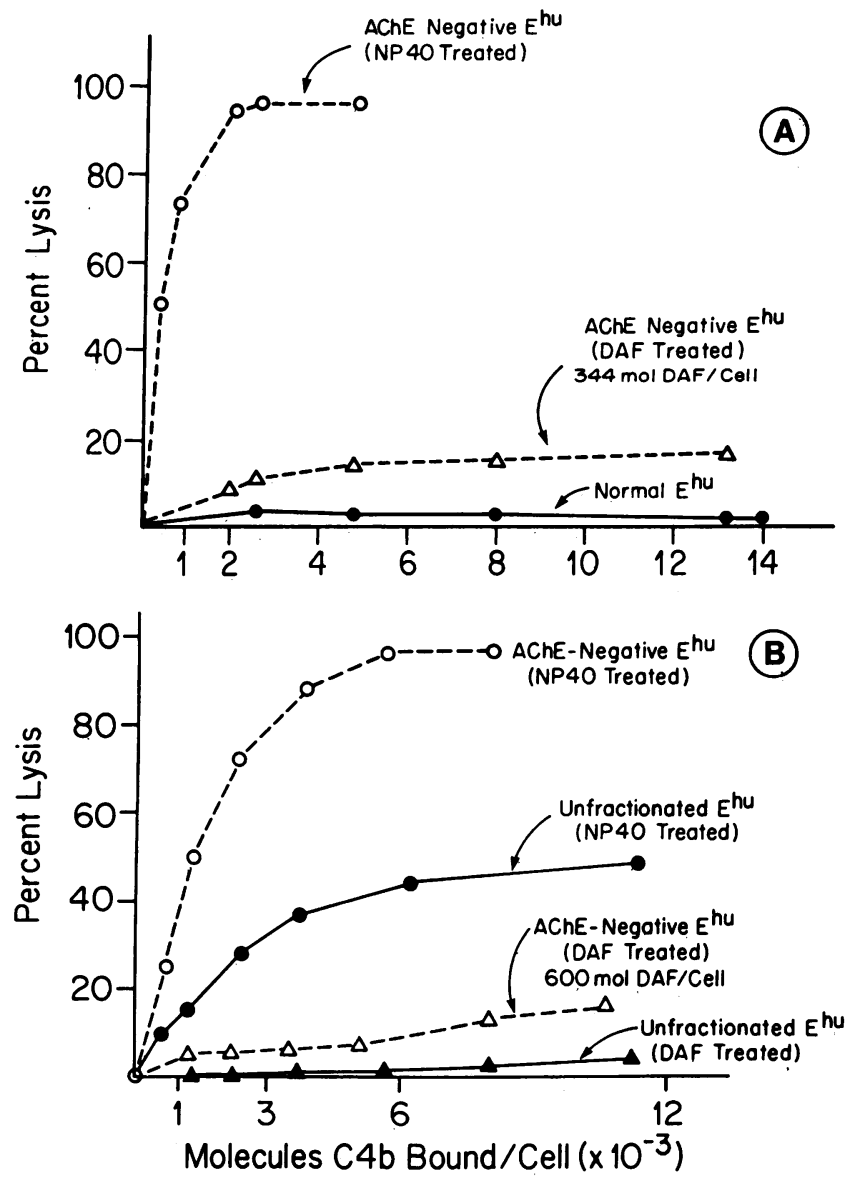

Figure 3. Inhibitory effect of incorporated DAF on C4b2a assembly on $\mathrm{PNH} \mathrm{E}^{\text {hu }}$. $\mathrm{E}^{\text {hu }} \mathrm{ACl}$ were incubated with increasing concentrations of $\mathrm{C} 4$. Aliquots of the resulting $\mathrm{E}^{\mathrm{hu}} \mathrm{AC14}$, bearing increasing numbers of $\mathrm{C} 4 \mathrm{~b}$ per cell, were incubated at $30^{\circ} \mathrm{C}$ for $4-6 \mathrm{~h}$ with DAF or with NP40-containing buffer as control. After thorough washing, the DAFtreated or control cells were incubated with excess human $C 2$ and guinea pig C3-9 (see Methods) and lysis quantitated. Percent lysis of the cells is shown as a function of the number of deposited C4b per $E^{\text {hu }}$. The results of studies with normal and AChE-negative $E^{\text {hu }}$ from PNH patient G.R. are shown in $(A)$ and with unseparated and AChEnegative $E^{\text {hu }}$ from patient M.A. in $(B)$. The incorporation of 344 and 600 molecules of DAF per cell, respectively, as determined by two-site radioimmunometric assay, markedly reduced the abnormal C4b2a assembly by the PNH cells.

in previous studies $(8,12)$. The incorporated DAF was thus fully functional.

The effect of the incorporated DAF on the sensitivity of the PNH cells in the CLS assay was next examined. The results of one study with PNH II cells are illustrated in Fig. 4. Restoration of DAF activity to PNH II $\mathrm{E}^{\text {hu }}$ (Fig. $4 \mathrm{~A}$ ) reduced their sensitivity in CLS to near normal levels. Conversely (Fig. $4 \mathrm{~B}$ ), treatment of normal $E^{\text {hu }}$ with polyclonal anti-DAF antibodies $(30 \mu \mathrm{g} / \mathrm{ml}$ IgG) increased their sensitivity in CLS to the level of PNH II cells. Augmenting the concentration of anti-DAF antibody 3or 10 -fold further (to $300 \mu \mathrm{g} / \mathrm{ml} \mathrm{IgG)} \mathrm{had} \mathrm{no} \mathrm{additional} \mathrm{effect.}$ In contrast, in multiple studies (see Table II), DAF reconstitution had only a minimal effect ( $<30 \%$ reduction) on the sensitivity of PNH III cells in CLS (Fig. 5). Augmenting the incorporated 

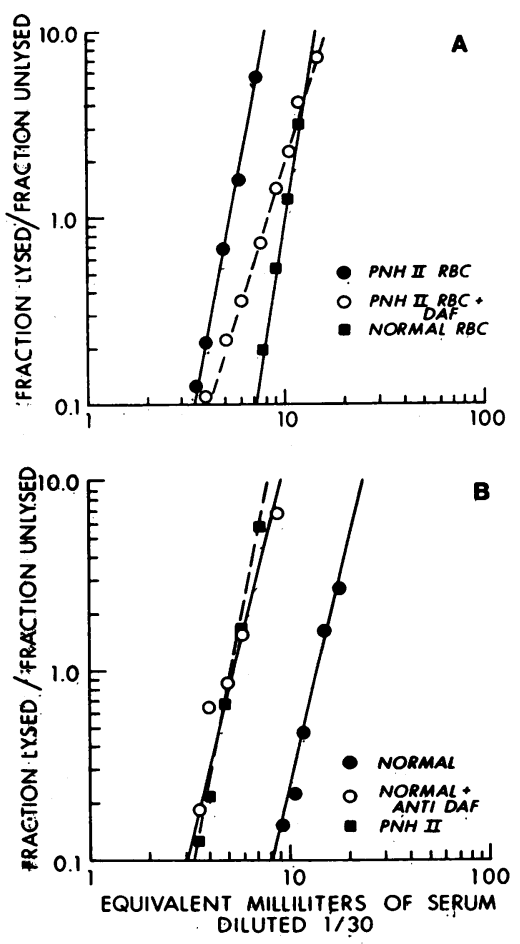

cells. In this and other experiments the DAF sensitivity of the PNH II cells to near normal levels. Analyses with the two-site radioimmunometric assay for DAF showed that 645 molecules per $\mathrm{E}^{\text {hu }}$ had incorporated. In $(B)$, normal $\mathrm{E}^{\text {hu }}$ were pretreated with polyclonal anti-DAF antibodies $(300 \mu \mathrm{g} / \mathrm{ml})$ or with buffer as control. The sensitivities of the antibody-treated and control cells were then compared with untreated PNH II E ${ }^{\text {hu }}$ from patient W.I. The antiDAF treatment of the normal $\mathrm{E}^{\text {hu }}$ increased their sensitivity to that of the PNH II $E^{\text {hu }}$.

DAF levels (Table III) had little additional effect. Even after incorporation of 573 DAF molecules per $\mathrm{E}^{\text {hu }}$, sensitivity of the DAF-treated PNH III cells was still 10 times that of normal cells (Table III).

Table II. Incorporation of DAF into PNH Erythrocyte Membranes

\begin{tabular}{|c|c|c|c|c|c|}
\hline \multirow[b]{2}{*}{ Pațient ID } & \multirow[b]{2}{*}{$\begin{array}{l}\text { \% Affected } \\
\text { cells }\end{array}$} & \multicolumn{2}{|c|}{$\begin{array}{l}\text { Unfractionated } \\
\text { erythrocytes }\end{array}$} & \multicolumn{2}{|c|}{$\begin{array}{l}\text { Purified AChE- } \\
\text { negative } \\
\text { erythrocytes }\end{array}$} \\
\hline & & $\begin{array}{l}\text { NP40- } \\
\text { treated }\end{array}$ & $\begin{array}{l}\text { DAF- } \\
\text { treated }\end{array}$ & $\begin{array}{l}\text { NP40- } \\
\text { treated }\end{array}$ & $\begin{array}{l}\text { DAF- } \\
\text { treated }\end{array}$ \\
\hline & & \multicolumn{2}{|c|}{ molecules DAF/cell } & \multicolumn{2}{|c|}{ molecules DAF/cell } \\
\hline \multicolumn{6}{|l|}{ PNH III } \\
\hline D.I. & 58 & 361 & 430 & $<10$ & 275 \\
\hline P.H. & 34 & 963 & 1187 & $<10$ & 223 \\
\hline F.R. & 52 & 1471 & 2804 & 0 & 585 \\
\hline G.R. (IIIb)* & 35 & 774 & 1376 & 0 & 573 \\
\hline \multicolumn{6}{|l|}{ PNH II } \\
\hline W.I. & 42 & 1505 & 2150 & $<10$ & - \\
\hline B.A. & 90 & 172 & 1118 & 0 & 722 \\
\hline
\end{tabular}

Normal erythrocytes have $\sim 2000 \mathrm{~mol} \mathrm{DAF} /$ cell. * Comparable sensitivity to PNH III in reactive lysis but sensitivity to classical pathway lysis intermediate between PNH II and III.

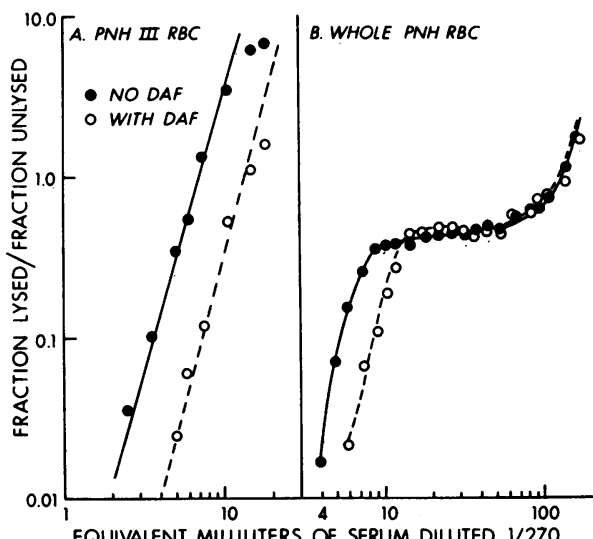

Figure 5. Effect of DAF on CLS of PNH III E ${ }^{\text {hu }}$. Cells were treated with DAF or NP40 detergent containing buffer and then tested for their complement sensitivity as described in the legend of Fig. 4. $(A)$ shows the results with separated AChE-negative PNH III $\mathrm{E}^{\text {hu }}$ and $(B)$ the results with unseparated PNH III $\mathrm{E}^{\text {hu. }}$.

The effect of DAF reconstitution of PNH III $E^{\text {hu }}$ on the sensitivity of PNH III cells to passive lysis in cobra venom factortreated human serum was next evaluated. The results of a typical study are shown in Fig. 6. Significant lysis of PNH III E ${ }^{\text {hu }}$ occurred in 1/64 cobra venom factor-treated serum, whereas minimal lysis of normal $E^{\text {hu }}$ occurred in $1 / 8$ cobra venom factortreated serum. Reconstitution of the PNH cells with DAF did not diminish their sensitivity to lysis in this assay. Conversely, prior treatment of the normal cells with polyclonal anti-DAF antibodies (30-300 $\mu \mathrm{g} / \mathrm{ml} \mathrm{IgG}$ ) did not abrogate their inherent resistance. In three other studies with both unfractionated and purified AChE-negative cells (Table II), incorporation of up to 585 DAF molecules per cell (the maximal attainable DAF level with the reagents used) had no effect. The inability of DAF to influence this terminal pathway defect under conditions in which inhibition of $\mathrm{C} 3$ convertase assembly was restored argues that a third abnormality of the membrane must exist in PNH III cells.

The evaluation of DAF levels in AChE-positive $E^{\text {hu }}$ of the PNH patients by calculation from immunoradiometric data had indicated that complement-insensitive (PNH I) $\mathrm{E}^{\text {hu }}$ are partially DAF-deficient (Table I). In the final series of studies, comple-

Table III. Effect of Incorporated DAF Molecules on CLS of PNH Erythrocytes

\begin{tabular}{|c|c|c|c|c|}
\hline \multirow[b]{2}{*}{$\begin{array}{l}\text { DAF } \\
\text { Concentration }\end{array}$} & \multicolumn{2}{|c|}{ PNH III E } & \multicolumn{2}{|c|}{ PNH I E } \\
\hline & $\begin{array}{l}\text { DAF- } \\
\text { treated }\end{array}$ & $\begin{array}{l}\text { NP40- } \\
\text { treated }\end{array}$ & $\begin{array}{l}\text { DAF- } \\
\text { treated }\end{array}$ & $\begin{array}{l}\text { NP40- } \\
\text { treated }\end{array}$ \\
\hline \multicolumn{5}{|l|}{$\mu g / m l$} \\
\hline $12^{\ddagger}$ & $35.5^{6}$ & 41.0 & 3.1 & 3.1 \\
\hline 24 & 33.7 & 45.0 & 2.6 & 3.3 \\
\hline 48 & $30.0^{\prime \prime}$ & 43.5 & 1.7 & 3.0 \\
\hline
\end{tabular}

* CLS H50 units.

${ }^{\ddagger} \mathrm{E}^{\text {hu }}$ (from patient G.R.) were incubated at $30^{\circ} \mathrm{C}$ for $10 \mathrm{~h}$ with decreasing dilutions of either DAF-NP40 or NP40 alone in isoionic veronal buffer. After washing, the treated cells were assayed for CLS as described in Methods.

Normal range $\leqslant 2 \mathrm{U}$.

" $573 \mathrm{~mol} \mathrm{DAF}$ incorporated/cell. 


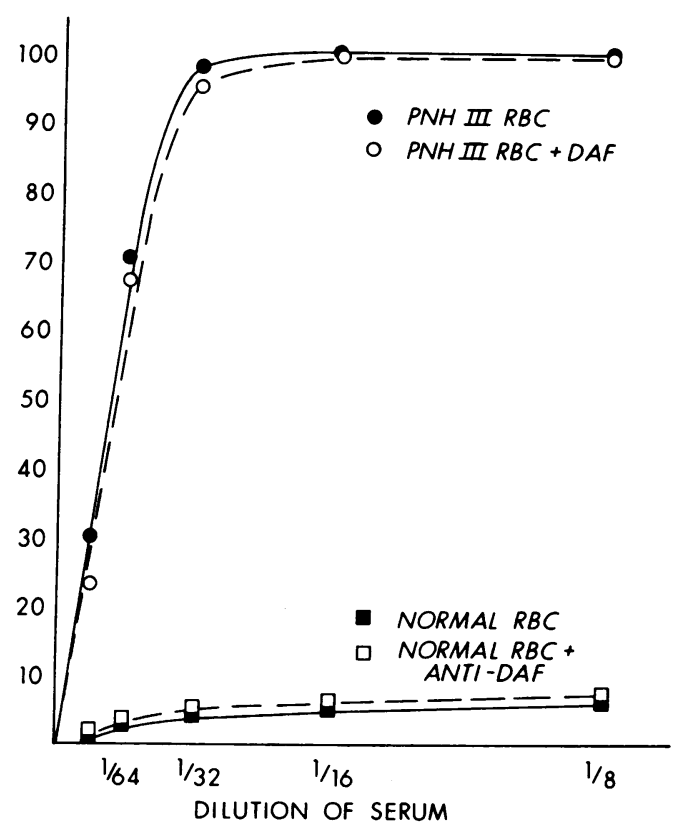

Figure 6. Effect of DAF and of anti-DAF antibodies on the susceptibility of PNH and of normal $E^{\text {hu }}$ to reactive lysis. Normal $E^{\text {hu }}$ were pretreated with polyclonal anti-DAF antibodies $(30-300 \mu \mathrm{g} / \mathrm{ml} \mathrm{IgG)}$ or with buffer as control, and purified AChE-negative PNH $E^{\text {hu }}$ from patient G.R. were pretreated with DAF or with NP40 detergent as control. Cobra venom factor:Bb complexes, prepared as described in Methods, were added to mixtures of the $E^{\text {hu }}$ in decreasing dilutions (1:64 to 1:4) of normal human serum in metal-chelating veronal buffer. After incubation at $37^{\circ} \mathrm{C}$ for $2 \mathrm{~h}$, additional metal-chelating veronal buffer was added, the tubes centrifuged, and lysis quantitated. Percent lysis of the cells is shown as a function of the serum dilution. The anti-DAF treatment did not impair the natural resistance of the normal $\mathrm{E}^{\text {hu }}$ to lysis, and the DAF treatment did not reduce the abnormal lytic sensitivity of the PNH III $\mathrm{E}^{\text {hu }}$. Analyses with the two-site radioimmunometric assay for DAF showed that in the case of the PNH $\mathrm{E}^{\text {hu }} 573$ DAF molecules had incorporated per cell.

ment-sensitive $E^{\text {hu }}$ from two of the patients with PNH III $E^{\text {hu }}$ were selectively lysed with cobra venom factor-treated serum, and the remaining complement-insensitive PNH I $E^{\text {hu }}$ examined directly for DAF and AChE expression by flow cytometry. The results are shown in Fig. 7. Fig. 7, $A$ and $B$ show the broad distribution of DAF and $\mathrm{AChE}$ in normal $\mathrm{E}^{\text {hu }}$. Fig. 7, $C-F$ show the distributions of the two proteins in unseparated $E^{\text {hu }}$ of patients M.A. and F.R., respectively, and in purified PNH I $E^{\text {hu }}$ from each surviving after reactive lysis. In the left hand panels, the numbers under the peaks give the measured DAF contents as determined by radioimmunometric assay. As can be seen, levels of both DAF and AChE in PNH I cells were markedly reduced compared with normal, demonstrating that PNH I cells in these patients are abnormal.

\section{Discussion}

Previous studies have shown that DAF is deficient in complement-sensitive $\mathrm{E}^{\text {hu }}$ of PNH patients $(2-4)$ and that the DAF deficiency is causally related to the heightened sensitivity of the cells to lysis (12). The main finding of the present study is that although the DAF defect accounts for excessive C3b uptake by

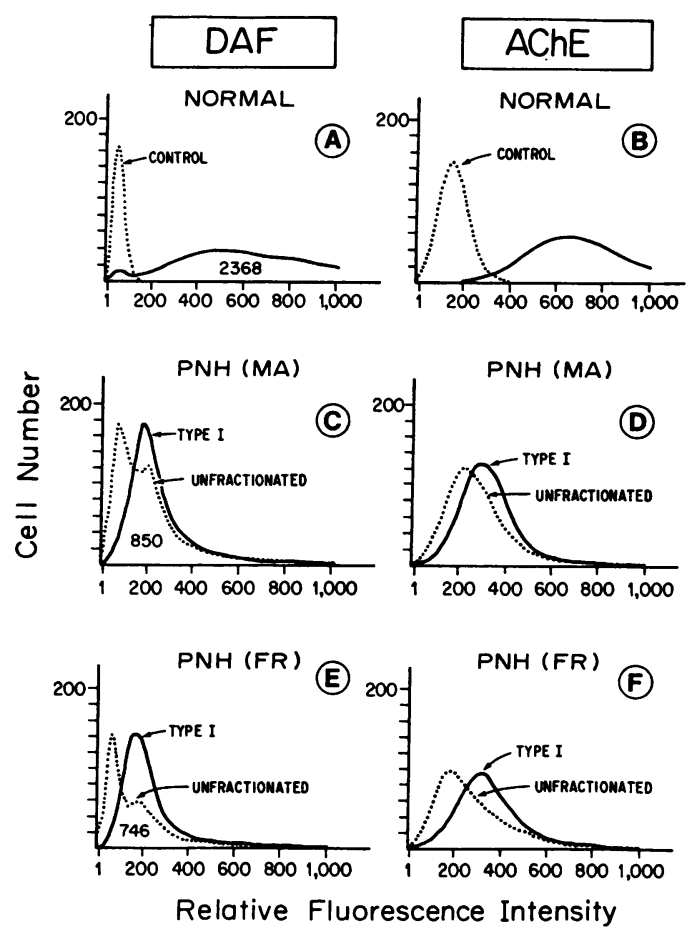

Figure 7. FACS analyses of DAF and AChE in purified PNH I E ${ }^{\text {hu }}$ from two patients. $E^{\text {hu }}$ were stained with pooled anti-DAF, anti-AChE, or nonrelevant antimalaria monoclonals as control followed by fluorescein-isothiocyanate-labeled goat anti-mouse Ig as in Fig. 1. Analyses with anti-DAF monoclonals are shown in the left hand panels and with anti-AChE monoclonals in the right hand panels. Control studies using normal $\mathrm{E}^{\text {hu }}$ are shown in $(A)$ and $(B)$. Solid lines show the results with anti-DAF and dashed lines the results with nonrelevant antimalaria monoclonals. Studies with PNH patients M.A. and F.R. are shown in $(C)$ and $(D)$, and $(E)$ and $(F)$, respectively. In these cases, solid lines show the results with purified complement-insensitive PNH I $E^{\text {hu }}$ and dashed lines the results with unfractionated $E^{\text {hu }}$. The numerical values in the left hand panels are the measured DAF contents in the DAF-positive cells as determined by radioimmunometric assay.

the $E^{\text {hu }}$, the marked lytic susceptibility of PNH III $E^{\text {hu }}$ and other functional abnormalities of the cells, e.g. AChE deficiency, do not derive from DAF deficiency alone. Rather, these characteristic defects of PNH occur as a result of alterations in multiple membrane components.

One problem that has complicated the characterization of these and other membrane alterations that have been described in PNH (1) has been the mixture in the blood of PNH patients of complement-sensitive and complement-insensitive cell populations. Separation of AChE-negative $E^{\text {hu }}$ subpopulations by cell-affinity chromatography in the present study, and examination of the purified cells by radioimmunometric assays (Table I) and by FACS analyses (Fig. 1) revealed that the DAF and AChE deficiencies completely overlap in the same cells. Evaluation of the cells in functional assays with whole human serum and cobra venom factor-treated human serum (Figs. 5 and 6) showed that in PNH III $E^{\text {hu }}$, the defect in terminal pathway restriction additionally resides in these same cells. The findings that the DAF, AChE, and terminal pathway restriction deficits each constitute profound abnormalities and precisely coincide with the complement-sensitive $\mathrm{E}^{\text {hu }}$ population suggest that they represent underlying defects that arise primarily in the cells. 
The results of our measurements of CR1 levels in purified and unfractionated cells may help to clarify previous reports by others that $\mathrm{CR} 1$ expression in PNH $\mathrm{E}^{\text {hu }}$ can fall within the broad normal range of values $(34)$ or can be reduced $(4,35)$. In contrast to the abnormalities of the above three factors, the reduction in CR 1 expression was only partial. Moreover, differently from the defects in the above factors, it was similarly distributed between complement-sensitive and -insensitive $\mathrm{E}^{\text {hu }}$ populations. These findings raise the possibility that the CR1 defect may arise secondarily. Levels of $E^{\text {hu }}$-associated CR1 are diminished in conditions associated with heightened activity of the complement system and the extent of the reduction is reciprocally related to acquisition of $\mathrm{C} 3$ activation fragments on the cells $(35,36)$. Increased levels of such fragments have been detected on PNH $E^{\text {hu }}$ (35), suggesting that the CR1 defect in PNH might likewise arise as a consequence of increased rates of complement activation in PNH blood. Such a mechanism could account for the presence of the defect in both complement-sensitive and -insensitive $E^{\text {hu }}$ populations.

Although the use of the anti-DAF (2-4) and anti-AChE (32) antibodies has demonstrated that the $\sim 70-\mathrm{kD}$ proteins associated with these two functional activities are deficient in PNH $E^{\text {hu }}$, it has not been previously established whether the two defects are due to different abnormalities. The selective immunoprecipitation of DAF and AChE by the respective monoclonals (Fig. 2) unequivocally demonstrates that they are in fact different proteins (37) and avoids uncertainties arising from interference by anti-glycophorin antibodies within polyclonal anti-DAF antisera (38). Although association of the two proteins in the membrane of intact $E^{\text {hu }}$ cannot be excluded, their lack of coprecipitation argues that they are not anchored in the membrane covalently by a common linking molecule. The limitation of the inhibitory effects of anti-AChE and anti-DAF antibodies to the activities associated with their respective antigens on normal $E^{\text {hu }}$ and the failure of DAF reconstitution to augment $\mathrm{AChE}$ activity in PNH $E^{\text {hu }}$ indicate that the functional activities of $\mathrm{AChE}$ and DAF in $E^{\text {hu }}$ membranes are independently mediated.

PNH III $E^{\text {hu }}$ are characterized by their abnormal susceptibility to reactive lysis in addition to their exaggerated uptake of $\mathrm{C} 3 \mathrm{~b}(1,15,16)$. This functional defect is due to an inability of their membranes to circumvent damage by the membrane attack complex, according to current evidence, at the level of $\mathrm{C} 9$ (13, 14). The relationship of this defect, however, to DAF deficiency previously was not clarified. It has been suggested that the greater passive lysis susceptibility of PNH III than PNH II E ${ }^{\text {hu }}$ could be due to more profound DAF-deficiency in the PNH III cells (3, 11). Of relevance, it has been reported that cell-bound $\mathrm{C} 3 \mathrm{~b}$ might enhance C9 insertion, providing a potential mechanism for a DAF effect (14). Several findings in the present study argue against this possibility and provide strong support for the alternative suggestion (39) that the two phenomena are mediated by different mechanisms. Analysis of purified AChE-negative PNH II and PNH III E $E^{\text {hu }}$ by radioimmunometric assay and flow cytometry revealed that both are totally DAF-deficient (Table I, Fig. 1) suggesting that an additional defect must be present in the PNH III cells. Despite abrogation of DAF activity as evidenced by uptake of $10,000 \mathrm{C} 3 \mathrm{~b}$ molecules by the cells and brisk lysis in heterologous guinea pig C5-9, anti-DAF treatment of normal $\mathrm{E}^{\text {hu }} \mathrm{AC} 1423$ did not render the intermediates susceptible to lysis in homologous C5-9. Similarly, exposure of normal $E^{\text {hu }}$ to 10-fold higher concentrations of anti-DAF antibodies than necessary to overcome resistance to $C 3$ convertase assembly (12) increased the sensitivity of the normal cells in the CLS assay only three- to fivefold (to that of PNH II $\mathrm{E}^{\text {hu}}$ ) (Fig. 4), and did not render the cells susceptible to passive lysis in cobra venom factor-treated human serum (Fig. 6). Finally, reconstitution of PNH III $E^{\text {hu }}$ with DAF in amounts sufficient to restore their ability to restrict $\mathrm{C} 4 \mathrm{~b} 2 \mathrm{a}$ assembly (12) reduced their sensitivity in CLS by < 30\% (Fig. 5) and had no discernable effect on their vulnerability to passive lysis (Fig. 6). The finding that polyclonal or pooled monoclonal anti-AChE antibodies, alone or in combination with the anti-DAF antibodies, also did not enhance the sensitivity of the $\mathrm{C} 3 \mathrm{~b}$-bearing normal $\mathrm{E}^{\text {hu }}$ intermediates to homologous C5-9 argues that the entity responsible for resistance to reactive lysis is not DAF or AChE, and therefore that PNH III $E^{\text {hu }}$ are abnormal with respect to a third activity.

Membrane factors that can inhibit $\mathrm{C} 9$ polymerization and thereby limit the activity of the membrane attack complex have been reported in extracts of $E^{\text {hu }}$ stroma by E. Podack, New York Medical College, Valhalla, NY (personal communication) and by Zalman and Müller-Eberhard (40). The activity detected by Podack elutes from DEAE-Sephacel at higher ionic strength than DAF and migrates as an $\sim 80-\mathrm{kD}$ molecule on SDS-PAGE, whereas that described by Zalman and Müller-Eberhard has an apparent $M_{\mathrm{r}}$ of $65 \mathrm{~K}$. Another terminal pathway inhibitory factor with the ability to bind to $\mathrm{C} 8$ and block its interaction with $\mathrm{C} 9$ has been isolated from extracts of $\mathrm{E}^{\text {hu }}$ stroma by Schonermark et al. (41). The relationship, however, of this factor to the above inhibitors of $\mathrm{C} 9$ polymerization has not yet been investigated.

The demonstration in this study that the characteristic abnormalities of PNH are a result of deficiencies in multiple membrane components rather than in DAF alone has important implications concerning the mechanism of the PNH defect. Previous findings that small amounts of DAF antigen are detectable in affected leukocytes of patients (9) and that, when cultured in vitro, DAF-positive erythroid precursors in patients' marrow give rise to DAF-negative erythroid colonies (42) suggest that the diminished DAF expression in PNH is not due to absence or nonfunction of the DAF structural gene. That deficient expression of the factors does not arise from the failure of PNH membranes to hold the factors or to support their function is indicated by the ability of exogenous DAF to incorporate into PNH $E^{\text {hu }}$ and to restore the resistance of the affected cells to C3 convertase assembly (12). The simultaneous deficiency of the three entities could arise from a biosynthetic defect in a structural element shared by the three factors. Structural analyses of $E^{\text {hu }}$ $\mathrm{AChE}$ and DAF have revealed the presence of a covalently linked glycolipid at the $\mathrm{COOH}$-terminus of each molecule rather than hydrophobic amino acids typical of conventional membrane polypeptide anchors (43-47). This non-amino acid anchor is comprised of fatty acids, inositol, and an oligosaccharide and is closely similar in both proteins (48). In AChE, this anchoring structure has been shown to be linked through an ethanolamine to the $\mathrm{COOH}$-terminal amino acid of $\mathrm{AChE}$ polypeptide and in studies of DAF, there is evidence that it is incorporated posttranslationally before addition of $O$-linked sugars to DAF in the Golgi. If the putative terminal pathway inhibitory molecule shares the same glycolipid anchoring structure, a defect in the assembly of this structure or its attachment to the respective proteins could lead to deficient expression of all three molecules.

A biosynthetic defect in a structure common to the proteins, however, would not account for the sporadic occurrence of defects in only two of the factors and thereby would not explain the findings in the present study that PNH II and PNH III $\mathbf{E}^{\text {hu }}$ 
differ with respect to the absence or presence of a defect in terminal pathway restriction (Figs. 5 and 6). It is possible that different biosynthetic defects could give rise to the two classes of PNH cells. It is alternatively possible that PNH involves a regulatory rather than a biosynthetic defect and that expression of DAF and AChE and expression of the entity responsible for terminal pathway restriction are independently controlled. Recent findings that normal platelets manifest DAF activity $(9,10$, 49) but not terminal pathway restriction (49) support this possibility. In either case, it would not be surprising if more than one alteration could lead to DAF deficiency and the consequent clinical expression of $\mathrm{PNH}$ and if the changes that characterize PNH II and III cells could arise by different mechanisms.

Current evidence indicates that PNH is a clonal disorder (1). For this and other reasons, it has been assumed that the complement-insensitive (PNH I) $\mathrm{E}^{\text {hu }}$ in PNH blood are products of natural hematopoiesis and remain entirely normal. Our observation that DAF and AChE levels are reduced in the PNH I cells of most patients (Table I and Fig. 7) raises the possibility that PNH I cells could also derive from abnormal progenitors. Alternatively, it is possible that their DAF alterations could arise secondarily as a consequence of effects of the DAF-deficient $E^{\text {hu }}$ population on them in the circulation (or on their precursors in the marrow) or as a result of the complement dysregulation that occurs in PNH blood.

\section{Acknowledgments}

The authors thank Dr. M. Berger and Dr. Dee Dee Stafford for helpful discussion and Katie Montgomery for manuscript preparation.

This work was supported in part by grants from the Arthritis Foundation, Systemic Lupus Erythematosus Society, American Diabetes Association, and National Institutes of Health (grants AI-13224 and AI23598).

\section{References}

1. Rosse, W. F., and C. J. Parker. 1984. Paroxysmal nocturnal haemoglobinuria. Clin. Haematol. 14:105-125.

2. Pangburn, M. K., R. D. Schreiber, J. S. Trombold, and H. J. Müller-Eberhard. 1983. Paroxysmal nocturnal hemoglobinuria: deficiency in factor H-like functions of the abnormal erythrocytes. J. Exp. Med. 157:1971-1980.

3. Nicholson-Weller, A., J. P. March, S. I. Rosenfeld, and K. F. Austen. 1983. Affected erythrocytes of patients with paroxysmal nocturnal hemoglobinuria are deficient in the complement regulatory protein, decay accelerating factor. Proc. Natl. Acad. Sci. USA. 80:5066-5070.

4. Pangburn, M. K., R. D. Schreiber, and H. J. Müller-Eberhard. 1983. Deficiency of an erythrocyte membrane protein with complement regulatory activity in paroxysmal nocturnal hemoglobinuria. Proc. Natl. Acad. Sci. USA. 80:5430-5434.

5. Hoffman, E. M. 1969. Inhibition of complement by a substance isolated from human erythrocytes. I. Extraction from human erythrocyte stromata. Immunochemistry. 6:391-403.

6. Hoffman, E. M. 1969. Inhibition of complement by a substance isolated from human erythrocytes. II. Studies on the site and mechanism of action. Immunochemistry. 6:405-419.

7. Nicholson-Weller, A., J. Burge, D. T. Fearon, P. F. Weller, and K. F. Austen. 1982. Isolation of a human erythrocyte membrane glycoprotein with decay-accelerating activity for $\mathrm{C} 3$ convertases of the complement system. J. Immunol. 129:184-189.

8. Medof, M. E., T. Kinoshita, and V. Nussenzweig. 1984. Inhibition of complement activation on the surface of cells after incorporation of decay-accelerating factor (DAF) into their membranes. J. Exp. Med. 160:1558-1578.
9. Kinoshita, T., M. E. Medof, R. Silber, and V. Nussenzweig. 1985. Distribution of decay accelerating factor in the peripheral blood of normal individuals and patients with paroxysmal nocturnal hemoglobinuria. $J$. Exp. Med. 162:75-92.

10. Nicholson-Weller, A., J. P. March, C. E. Rosen, D. B. Spicer, and K. F. Austen. 1985. Surface membrane expression by human blood leukocytes and platelets of decay accelerating factor, a regulatory protein of the complement system. Blood. 65:1237-1244.

11. Nicholson-Weller, A., D. B. Spicer, and K. F. Austen. 1985. Deficiency of the complement regulatory protein "decay accelerating factor" on membranes of granulocytes, monocytes, and platelets in paroxysmal nocturnal hemoglobinuria. N. Engl. J. Med. 312:1091-1097.

12. Medof, M. E., T. Kinoshita, R. Silber, and V. Nussenzweig. 1985. Amelioration of lytic abnormalities of paroxysmal nocturnal hemoglobinuria with decay-accelerating factor. Proc. Natl. Acad. Sci. USA. 82: 2980-2984.

13. Hansch, G. M., C. H. Hammer, P. Vanguri, and M. L. Shin. 1981. Homologous species restriction in lysis of erythrocytes by terminal complement proteins. Proc. Natl. Acad. Sci. USA. 78:5118-5121.

14. Hu, V. W., and M. L. Shin. 1984. Species-restricted target cell lysis by human complement: complement-lysed erythrocytes from heterologous and homologous species differ in their ratio of bound to inserted C9. J. Immunol. 133:2133-2137.

15. Packman, C. H., S. I. Rosenfeld, D. E. Jenkins, Jr., P. A. Thiem, and J. P. Leddy. 1979. Complement lysis of human erythrocytes: differing susceptibility of two types of paroxysmal nocturnal hemoglobinuria cells to C5b-9. J. Clin. Invest. 64:428-433.

16. Rosenfeld, S. I., D. E. Jenkins, and J. P. Leddy. 1985. Enhanced reactive lysis of paroxysmal nocturnal hemoglobinuria erythrocytes by C5b-9 does not involve increased C7 binding or cell-bound C3b. J. Immunol. 134:506-511.

17. Hu, V. W., and A. Nicholson-Weller. 1985. Enhanced complement-mediated lysis of type III paroxysmal nocturnal hemoglobinuria erythrocytes involves increased $\mathrm{C} 9$ binding and polymerization. Proc. Natl. Acad. Sci. USA. 82:5520-5524.

18. Dykman, T. R., J. L. Cole, K. Iida, and J. P. Atkinson. 1983. Polymorphism of human erythrocyte $\mathrm{C} 3 \mathrm{~b} / \mathrm{C} 4 \mathrm{~b}$ receptor. Proc. Natl. Acad. Sci. USA. 80:1698-1702.

19. Kerr, M. A. 1980. The second component of human complement. Methods Enzymol. 80:54-64.

20. Tack, B. F., J. Janatova, M. L. Thomas, R. A. Harrison, and C. H. Hammer. 1980. The third, fourth, and fifth components of human complement: isolation and biochemical properties. Methods Enzymol. 80:64-101.

21. Nelson, R. A., Jr., J. Jensen, I. Gigli, and N. Tamura. 1966. Methods for the separation, purification and measurement of nine components of hemolytic complement in guinea pig serum. Immunochemistry. 3:111-135.

22. Cooper, N. R., and H. J. Müller-Eberhard. 1970. The reaction mechanism of human $\mathrm{C} 5$ in immune hemolysis. J. Exp. Med. 132:775793.

23. Parker, C. J., P. J. Baker, and W. F. Rosse. 1983. Comparison of binding characteristics of factors $\mathrm{B}$ and $\mathrm{H}$ to $\mathrm{C} 3 \mathrm{~b}$ on normal and paroxysmal nocturnal hemoglobinuria erythrocytes. J. Immunol. 131: 2484-2489.

24. Fearon, D. T. 1979. Regulation of the amplification C3 convertase of human complement by an inhibitory protein isolated from human erythrocyte membrane. Proc. Natl. Acad. Sci. USA. 76:5867-5871.

25. Iida, K., R. Mornaghi, and V. Nussenzweig. 1982. Complement receptor (CR1) deficiency in erythrocytes from patients with systemic lupus erythematosus. J. Exp. Med. 155:1427-1438.

26. Rosse, W. F. 1973. Variations in the red cells in paroxysmal nocturnal haemoglobinuria. Br. J. Haematol. 24:327-342.

27. Fambrough, D. M., A. G. Engel, and T. L. Rosenberry. 1982. Acetylcholinesterase of human erythrocytes and neuromuscular junctions: homologies revealed by monoclonal antibodies. Proc. Natl. Acad. Sci. USA. 79:1078-1082.

28. Yoshida, N., R. Nussenzweig, P. Potocnjak, V. Nussenzweig, 
and M. Aikawa. 1980. Hybridoma produces protective antibodies directed against the sporozoite stage of malaria parasite. Science (Wash. DC). 207:71-73.

29. Brown, E. J., J. Ramsey, C. H. Hammer, and M. M. Frank. 1983. Surface modulation of classical pathway activation: $\mathrm{C} 2$ and $\mathrm{C} 3$ convertase formation and regulation on sheep, guinea pig, and human erythrocytes. J. Immunol. 131:403-408.

30. Rosse, W. F., and J. V. Dacie. 1966. Immune lysis of normal human and paroxysmal nocturnal hemoglobinuria (PNH) red blood cells. I. The sensitivity of PNH red cells to lysis by complement and specific antibody. J. Clin. Invest. 45:736-748.

31. Laemmli, U. K. 1970. Cleavage of structural proteins during the assembly of the head of bacteriophage T4. Nature (Lond.). 227:680-685.

32. Chow, F. L., S. E. Hall, W. F. Rosse, and M. J. Telen. 1986. Separation of the acetylcholinesterase-deficient red cells in paroxysmal nocturnal hemoglobinuria erythrocytes. Blood. 67:893-897.

33. Auditore, J. V., R. C. Hartmann, J. M. Flexner, and O. J. Balchum. 1960. The erythrocyte acetylcholinesterase enzyme in paroxysmal nocturnal hemoglobinuria. Arch. Pathol. 69:534-543.

34. Roberts, W. N., J. G. Wilson, W. Wong, D. E. Jenkins, Jr., D. T. Fearon, K. F. Austen, and A. Nicholson-Weller. 1985. Normal function of CR1 on affected erythrocytes of patients with paroxysmal nocturnal hemoglobinuria. J. Immunol. 134:512-517.

35. Ross, G. D., M. J. Walport, C. J. Parker, A. F. Leutine, C. R. Fuller, W. J. Yount, B. L. Myones, J. B. Winfield, and P. J. Lachmann. 1984. Acquired loss of erythrocyte (E) CR1 (C3b-receptor) in systemic lupus erythematosus (SLE) and other diseases with autoantibodies and/ or complement (C) activation. Arthritis Rheum. 27:528. (Abstr.)

36. Parker, C. J., C. M. Soldato, and M. J. Telen. 1984. Increased efficiency of binding of nascent $\mathrm{C} 3 \mathrm{~b}$ to the erythrocytes of chronic cold agglutinin disease. J. Clin. Invest. 74:1050-1062.

37. Medof, M. E., V. Nussenzweig, T. Kinoshita, S. Hall, A. Gottlieb, R. Silber, and W. F. Rosse. 1985. Nature of the PNH defect. Complement. 2:53. (Abstr.)

38. Sugarman, J., D. V. Devine, and W. F. Rosse. 1986. Structural and functional differences between decay-accelerating factor and red cell acetylcholinesterase. Blood. 68:680-684.
39. Hu, V. W., and M. L. Shin. 1984. Effect of dithiothreitol treatment of human erythrocytes on complement insertion and membrane properties. Fed. Proc. 43:1762. (Abstr.)

40. Zalman, L. S., L. M. Wood, and H. J. Müller-Eberhard. 1986. Isolation of a human erythrocyte membrane protein capable of inhibiting expression of homologous complement transmembrane channels. Proc. Natl. Acad. Sci. USA. 83:6975-6979.

41. Schonermark, S., E. W. Rauterberg, D. Roelcke, S. Lobe, and G. M. Hansch. 1984. A C8-binding protein on the surface of human erythrocytes is the inhibitor of lysis in a homologous system. Immunobiology. 68:103. (Abstr.)

42. Moore, J. C., M. M. Frank, and H. J. Müller-Eberhard. 1985. Decay accelerating factor is present on PNH progenitor cells but is lost during in vitro erythropoiesis. J. Exp. Med. 162:1182-1192.

43. Rosenberry, T. L., and D. M. Scoggin. 1984. Structure of human erythrocyte acetylcholinesterase. J. Biol. Chem. 259:5643-5652.

44. Medof, M. E., E. I. Walter, J. L. Rutgers, D. M. Knowles, and V. Nussenzweig. 1987. Identification of the complement decay-accelerating factor (DAF) on epithelium and glandular cells and in body fluids. J. Exp. Med. 165:848-864.

45. Dutta-Choudhury, T. A., and T. L. Rosenberry. 1984. Human erythrocyte acetylcholinesterase in an amphipathic protein whose short membrane binding domain is removed by papain digestion. J. Biol. Chem. 259:5653-5660.

46. Medof, M. E., E. I. Walter, W. L. Roberts, R. Haas, and T. L. Rosenberry. 1986. Decay accelerating factor of complement is anchored to cells by a C-terminal glycolipid. Biochemistry. 25:6740-6747.

47. Davitz, M., M. Low, and V. Nussenzweig. 1986. Release of decayaccelerating factor (DAF) from the cell membrane by phosphatidylinositol-specific phospholipase C (PIPLC). J. Exp. Med. 163:1150-1161.

48. Walter, E. I., W. L. Roberts, T. L. Rosenberry, and M. E. Medof. 1987. Analysis of fatty acids and inositol in the membrane anchor of human erythrocyte decay accelerating factor (DAF). Fed. Proc. 46:772. (Abstr.)

49. Devine, D. V., and W. F. Rosse. 1985. Deposition of C3 and C9 on normal and paroxysmal nocturnal hemoglobinuria platelets. Clin. Res. 33:545a. (Abstr.) 